ISSN 0258-7122

Bangladesh J. Agril. Res. 35(2) : 273-277, June 2010

\title{
EFFICACY OF MURIATE OF POTASH AND FOLIAR SPRAY WITH FUNGTCIDES TO CONTROL RED RUST DISEASE (Cephaleurous parasiticus) OF TEA
}

\author{
M. HUQ ${ }^{1}$, M. ALI' ${ }^{2}$ AND M. S. ISLAM ${ }^{3}$
}

\begin{abstract}
An experiment was conducted to find out the efficacy of muriate of potash applied as a potash fertilizer and foliar spray with Bordeaux mixture + Cupraneb 224 kg/ha, Copper Hydroxide@ 2.24 kg/ha and Carbcndazim @ 750 g /ha to control red rust disease (Cephaleuros parasiticus) of tea. All treatments with fungicides and application of MP caused reduction in severity of red rust and gave increase in yield of made tea over the control, where any fungicide or MP was not applied. The tea yield was negatively and nearly correlated with severity of red rust disease. The most effective treatment was application of the potash fertilizer (MP), which was followed by foliar spray with Copper Hydroxide and Carbendazim.
\end{abstract}

Keywords : Muriate of potash, foliar spray with fungtcides, red rust disease.

\section{Introduction}

Red rust is a predominant disease in tea garden caused by an algae, Cephaleuros parasiticus Karst (Sana, 1989; Huq et al., 2007). When tea plants are affected by red rust disease, the leaves become variegated (yellow or white). In extreme cases, red rust causes severe damage to young tea plants by killing stem tissues in patches. The algae produces minutes spores, especially on the stems of tea plants. The spores are produced within the sporangia at the apex of hyphae like vegetative body. After maturation, the sporangia are detached and spread easily by wind, rain, and dew to healthy tea plants and other host plants like Bogamedeloa, Albizzia molucana, A odoratissima, etc. and spores are released there. Red rust can attack both young and old tea plants under adverse conditions of soil and climate. The predisposing factors of the disease are mainly poor fertility, alkalinity and lack of aeration of the soil, hard pan, inadequate or complete absence of shade, drought and water logging (Sarmah, 1960). The disease is widely distributed in the zones of North-East India, Srilanka, and Bangladesh (Sana, 1989). The disease is most common in young tea, old tea bushes in seed baries and unthrifty tea sections. In Bangladesh, about 8-25\% tea estates are affected by this disease (Sana, 1989). The algae can infect the branches at any stage of growth. Once the branch is infected, the algae remain

${ }^{1}$ Chief Scientific Officer, ${ }^{2}$ Principal Scientific Officer, ${ }^{3}$ Scientific Officer, Bangladesh Tea Research Institute (BTRI), Srimangal, Moulvibazar, Bangladesh. 
latent for a year. In the following year, depending on the first rain fruiting bodies of the pathogen are produced (Huq et al., 2007).

Available literature in relation to control of the disease suggests that potash fertilizer plays an important role in red rust infection. Huq et al. (2007) reported that nitrogen and potash are major elements for the growth of tea plant. At low nitrogen level, tea plants become weak and vulnerable to the disease. Potassium plays an important role in developing bush frame as well as providing rigidity to the bushes. Incidence of red rust is low in the tea garden fertilized with a balance mixture of fertilizers including potash. Chaudhury and Ahsan (1976) reported that healthy leaves of clones and seedlings contain more nitrogen and potash than that of the red rust infected ones. Though red rust disease is a major threat to the Bangladesh Tea Industry, effective and acceptable management practices are yet to develop.

Considering the above facts, the present study was undertaken to find out the effect of potash fertilizer and foliar spray with some selected fungicides on severity of red rust disease and yield of tea.

\section{Materials and Method}

A field experiment was conducted during 2000 - 2007 in an experimental tea field of Bangladesh Tea Research Institute (BTRI), Srimangal to evaluate the efficacy of fungicides and MP to control red rust disease of tea. The treatments were, $\mathrm{T}_{1}$ control, $\mathrm{T}_{2}=$ Bordeaux mixture + Cupraneb @ $2.24 \mathrm{~kg} / \mathrm{ha}, \mathrm{T}_{3}=$ Copper Hydroxide @ $2.24 \mathrm{~kg} / \mathrm{ha}, \mathrm{T}_{4}=$ Carbendazim @ $750 \mathrm{~g} / \mathrm{ha}$ and $\mathrm{T}_{5}=$ Muriate of Potash (K) @ 210 $\mathrm{kg} / \mathrm{ha}$. The treatments were applied two times per year during March- April and second was in June- July. All of the fungicides were suspended in water and applied as foliar spray on the stem of bushes. Muriate of potash (MP) was applied as top dress near the base of tea plants. The doses of fungicides and MP frtilizer were selected according to the recommendations of BTRI.

The experiment was laid out in a candomized complete block design (RCBD) with three replications. The unit plot size was $7.15 \mathrm{~m} . \times 42 \mathrm{~m}$. Number of bushes in each plot was counted. To minimize the variation in per plot bush number, bushes in all unit plots of the experimental field were counted and divided by the total number of unit plots $(5 \times 3=15)$. The average number of bushes in each plot was considered for data computing.

Data on production of green leaves and severity of red rust disease were recorded. Green leaves were harvested at seven days interval maintaining plucking standard. Per plot yield of green leaves was recorded. The yield of green leaves in a unit plot was divided by actual number of bushes in that plot and multiplied by average number of bushes as computed before. Considering the plot size, the leaf yield per plot was converted into $\mathrm{kg} / \mathrm{ha}$. The yield was 
expressed in kilogram of made tea per hectare based on 23\% recovery. To collect data on severity of red rust, ten bushes were selected in each plot following simple random technique (Cochran, 1953). Close observation was made on the selected bushes and disease severity was graded on the basis of a 0-5 scale, where $0=$ no infection, $1=1-20 \%, 2=21-40 \% 3=41-60 \%$, $4=61-80 \%$, and $5=$ 81- 100\% infection (Rashid et al., 1987). The severity was expressed in percent disease index (PDI), which was computed following a standard formula as described below (Singh, 2000):

Percent Disease Index $(\mathrm{PDI})=\frac{\text { Sum of all disease ratings }}{\text { Total number of ratings } \mathrm{x} \text { maximum }} \times 100$ disease grade

Collected data were analyzed statistically by MSTAT-C computer programme. Means were compared following LSD test using the same computer programme.

\section{Results and Discussion}

All treatments with fungicides and application of MP, a potash feitilizer caused sigrnficant reduction in severity of red rust in terms of PDI and increase of yield of made tea as compared to control, where any fungicide or MP was not applied. Among the treatments, the highest reduction in PDI was obtained with MP, which was followed by Copper hydroxide and Caibendazim. They caused 46.71, 32.39, and 26.53\% reduction in PDI over control, respectively. The least effective treatment was Bordeaux mixture + Cupraneb, which gave only $2.23 \%$ reduction in PDI. The highest yield of tea was achieved with the potash fertilizer (MP), which was followed by Copper hydroxide, Carbendazim, and Bordeaux mixture + Cupraneb. The treatments gave 30.30, 28.93, 25.03, and $17.29 \%$ increased yield of made tea, respectively (Table 1).

Table 1. Effect of treatments with fungicides and potash fertilizer on severity of red rust (Cephaleuros parasiticus) and yield of tea.

\begin{tabular}{l|l|l|l|c}
\hline \multicolumn{1}{c}{ Treatments } & $\begin{array}{c}\text { Percent } \\
\text { disease index } \\
\text { (PDI) }\end{array}$ & $\begin{array}{c}\text { \% Reduction } \\
\text { in PDI over } \\
\text { control }\end{array}$ & $\begin{array}{c}\text { Yield of } \\
\text { made tea } \\
(\mathrm{kg} / \mathrm{ha})\end{array}$ & $\begin{array}{c}\text { \% Increase } \\
\text { in yield over } \\
\text { control }\end{array}$ \\
\hline $\begin{array}{l}\text { Control } \\
\text { Bordeaux mixture+ }\end{array}$ & 35.54 & - & 1330.52 & - \\
$\begin{array}{l}\text { Cupraneb @ 2.24 kg/ha } \\
\text { Copper Hydroxide@ 2.24 }\end{array}$ & 24.75 & 2.23 & 1560.21 & 17.29 \\
kg/ha & 32.39 & 1715.49 & 28.93 \\
$\begin{array}{l}\text { Carbendazim@750 g/ha } \\
\text { Muriate of Potash (K) }\end{array}$ & 26.11 & 26.53 & 1663.60 & 25.03 \\
@210 kg/ha & 18.94 & 46.71 & 1733.64 & 30.30 \\
\hline LSD (P=0.05) & & & & \\
\hline
\end{tabular}


The yield of made tea was linearly and inversely correlated with severity of red rust disease in terms of PDI. Their relationship could be expressed by the regression equation $\mathrm{Y}=0.02 \times+2.1573$, where $\mathrm{Y}$ represented yield of tea and $\mathrm{x}$ represented slop of the equation. The $\mathrm{R}^{2}$ value indicated that their relationship may be expressed by $74.44 \%$ (Fig. 1 ).

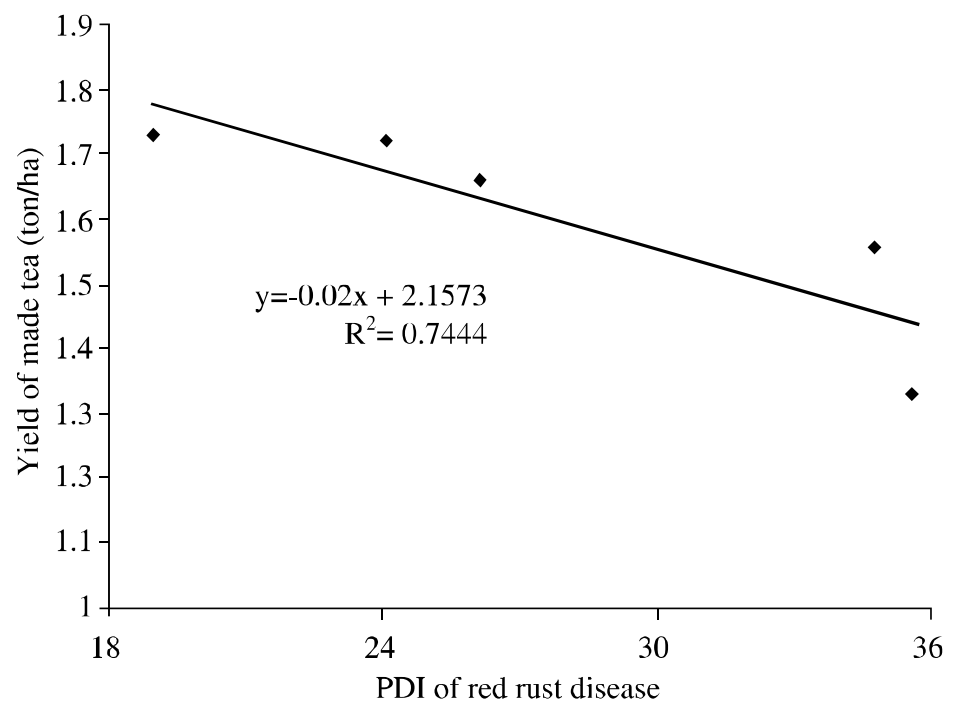

Fig. 1. Relationship of tea yield with severity of red rust disease of tea.

Results of the experiment revealed that foliar spray with Bordeaux mixture + Cupraneb $2.24 \mathrm{~kg} / \mathrm{ha}$, Copper hydroxide $224 \mathrm{~kg} / \mathrm{ha}$, and Carbendazim @750 g/ha and the application of Muriate of Potash (MP) @ 210 kg/ba reduced severity of red rust and increased yield of made tea considerably. Among the treatments, application of MP was most effective to control the disease. Most effective fungicidal treatments was Copper hydroxide $2.24 \mathrm{~kg} / \mathrm{ha}$. Similar findings were also reported by other investigators (Hudson et al., 2002; Chaudhury and Ahsan, 1976). Whenever the protective fungicide is sprayed, it goes contact to the spores and kill them. The algae can remain latent within the stem. Comparatively highest and similar yield was found in $\mathrm{T}_{5}$ and $\mathrm{T}_{3}$. Copper hydroxide may have the ability to kill the exposed spores and make them avirulent. From the result, it can be concluded that potash based fertilizer directly or indirectly can minimize the red rust disease as well as increase the production. Made tea yield may be increased by using only potash fertilizer in red rust affected area without spraying any fungicides for minimizing the red rust disease.

\section{References}

Chaudhury, S.H. and Q. Ahsan. 1976. Studies on the chemical composition of nornal vs variegated tea leaves aflcted by red rust disease. Tea J. Bangladeth 12(1): 5-11 
Cochran, W.G. 1953. Simple Random Sampling. Sampling Technique. John Wiley \& Sons, Inc. New York. pp. 11-12

Hudson, J.B., Durairaj and N. Muraleedharan. 2002. Functions of crop nutrients. Guidelines on Tea Culture in South India, UPASI, The Nilgiris, Tamilnadu: p. 84

Huq, M., M. Ali and M.S. Islam. 2007. Red rust disease of tea and its management. Memorandum no.1, BTRI, pp. 1-8

Rashld, A.Q.M.B, M.B. Meah and M. Jalaluddin. 1987. Effect of leaf blight caused by Drechslera sorokiniana on some yield components of wheat. Crop Protect. 6 (4): 256-260

Sana, D.L. 1989. Tea Science. Ashrafia Boi Ghar, Dhaka pp. 224-226.

Sannah, K. C. 1960. Red rust Cephaleuros parasiticus Karst. Disease of tea and associated crops in North - East India. Memorandum no. 26: 4446.

Singh, RS. 2000. Assessment of disease incidence and loss. Introduction to Principles of Pathology, $3^{\text {rd }}$ edition. p. 328 